\title{
A proteção à saúde e a segurança do trabalhador no ARE 664.335: uma análise sob a ótica da dignidade da pessoa humana
}

\author{
Health protection and worker safety in ARE 664.335: an analysis from \\ the perspective of human dignity
}

DÉBora de Jesus REZENDE BARCELOS

Pontifícia Universidade Católica de Minas Gerais

Resumo A aposentaria especial encontra-se entre o rol dos direitos mais relevantes e indispensáveis à realização da dignidade do indivíduo enquanto pessoa humana. Isso, porque tem como objetivo máximo a proteção à saúde e à segurança do trabalhador, de modo a afastá-lo o quanto antes de condições nocivas de trabalho. Porém, conforme será exposto no decorrer do presente ensaio, recentemente nos deparamos com um patente retrocesso social oriundo do ARE 664.335 que, em tese de repercussão geral, acabou por fixar interpretação restritiva ao alcance de um direito de tamanha essencialidade partindo de fundamentos altamente questionáveis. Não fosse o suficiente, a Reforma da Previdência, materializada segundo a última Emenda Constitucional de no 103 de 2019, vem reafirmando tal entendimento, sem que, contudo, sejam exibidos quaisquer argumentos lógicos ou científicos que justifiquem a obstacularização ao acesso desse direito. Nesse contexto, a realização de uma análise crítica da concepção adotada pelo STF no julgamento do aludido agravo em recurso extraordinário torna-se uma medida indispensável ao alcance da justiça, já que torna possível a averiguação das falhas do mais alto poder no Judiciário. Para tanto, a pesquisa em epígrafe utilizará uma técnica de metodologia ancorada no levantamento bibliográfico e no estudo do material doutrinário.

Palavras-chave: Saúde. Segurança. Aposentadoria Especial. Dignidade.

ABSTRACT Special retirement is among the list of the most relevant and indispensable rights for the realization of the dignity of the individual as a human person. That is why, its maximum objective is to protect the health and safety of workers, in order to remove them as soon as possible from harmful working conditions. However, as will be exposed in the course of this essay, we recently came across a patent social setback coming from ARE 664.335 that, in theory of general repercussion, ended up setting restrictive interpretation to the scope of such a fundamental right starting from highly questionable foundations. 
Were it not enough, the Pension Reform materialized according to the latest Constitutional Amendment No. 103 of 2019 has reaffirmed this understanding, without, however, presenting any logical or scientific arguments that justify the obstacles to accessing this right. In this context, conducting a critical analysis of the concept adopted by the STF in the judgment of the aforementioned appeal in an extraordinary appeal becomes an indispensable measure in the reach of justice, since it makes it possible to investigate the failures of the highest power in the Judiciary. For this, the research in title will use a methodology technique based on the bibliographical survey and the study of the doctrinal material.

Keywords: Health. Safety. Special Retirement. Dignity.

\section{INTRODUÇÃo}

A dignidade da pessoa humana é reconhecida hoje, ao menos na maioria dos ordenamentos, como o principal fundamento e a direção basilar de todo o sistema jurídico. De acordo com esse imperativo, o homem, assim compreendido enquanto todo e qualquer ser racional, deve ser tratado e contemplado como fim em si mesmo e não como um mero instrumento destinado à satisfação de interesses alheios previamente planejados. Possui, por conseguinte, um valor não relativo, como é por exemplo um preço, mas intrínseco, isto é, uma dignidade.

Essa observação é extremamente oportuna, uma vez que, a despeito de anos de desenvolvimento, com frequência nos deparamos com o renascimento contínuo de ideias do passado que, por muito tempo, foram consideradas mortas para sempre.

É o caso do ARE 664.335 que, em sede de repercussão geral, retira o manto protetivo à saúde e à segurança do trabalhador, atribuindo a este um ônus probante de eficácia duvidosa como requisito imprescindível à aquisição do direito à tão necessária aposentadoria especial.

Nesse cenário, a decisão em epígrafe do STF tem sido alvo de contundentes críticas, principalmente sob a ótica da dignidade do trabalhador, o que resulta na formulação do problema deste ensaio, cujo questionamento fundamental reside em averiguar se a decisão proferida no ARE 664.335 foi acertada ou não sob a ótica da dignidade da pessoa humana.

Para tanto, partiremos de uma breve contextualização histórica, onde será apresentada a importância de uma proteção efetiva à saúde e segurança dos obreiros, perpassando sobre algumas formas de se burlar legalmente essa proteção, entre elas, a monetização de riscos.

Posteriormente, a aposentadoria especial e suas implicações legais serão objeto de estudo, demonstrando o seu caráter "salvador" enquanto alternativa à degradação da saúde do segurado.

Para além, o ARE 664.335 também será exaustivamente explanado, com todas as especificidades de sua fundamentação, pois somente assim será possível a realização de uma análise crítica séria, tendo, efetivamente, a dignidade da pessoa humana enquanto principal elemento norteador.

Por fim, ressalta-se que a metodologia a ser utilizada passará pela técnica do levantamento bibliográfico, estudo de caso, pesquisa jurisprudencial e análise do material doutrinário. 


\section{A NECESSIDAde de PROTEÇÃo À SAÚde E SEgURANÇA do TRABALHADOR}

Os direitos sociais nascem e se estruturam depois de uma extensa luta social como reação ao cenário que se apresentou a Revolução Industrial, com a crescente e incontrolável exploração do homem pelo homem de forma cruel. São, pois, produtos da reação da classe trabalhadora ocorrida no século XIX contra o egoísmo e a utilização sem limites do trabalho humano.

Não se tratam, por conseguinte, de direitos gerados pacificamente, mas sim, arrancados a sangue e fogo do regime capitalista e liberal que dominava à época. Sua positivação resultou, entre outras benesses, na valorização do trabalho humano e no reconhecimento da imperiosidade de sua dignidade como um reflexo da dignidade da pessoa humana, já que restavam por consagrar a necessidade de uma intervenção estatal na atividade econômica e no contexto social, de modo a assegurar aos particulares um mínimo de igualdade material e liberdade real na vida em sociedade, bem como, a garantia de condições monetárias imprescindíveis para uma existência digna (GONÇALVES, 2007).

O Direito Civil, com suas regras privadas de mercado, não mais atendia aos anseios da classe trabalhadora oprimida e explorada diante da explosão da Revolução Industrial. A prática de que "o contrato faz lei entre as partes" colocava o trabalhador em posição inferior de barganha, que despossuído de qualquer bem de capital e, portanto, detentor unicamente de sua força de trabalho para garantir o sustento seu e de sua família, via-se, em face da necessidade, obrigado a aceitar todo e qualquer tipo de cláusula contratual, ainda que em condições desumanas e degradantes. Nesse viés, crianças e mulheres eram exploradas para trabalhos pesados, os salários eram aviltantes e as jornadas extremamente dilatadas, sem qualquer descanso, seja diário, semanal ou anual. Tudo isso em um ambiente de trabalho com péssimas condições de iluminação e ventilação, muitas vezes úmido, barulhento e repleto de detritos. Nessas circunstâncias, os riscos à saúde e à integridade física dos trabalhadores eram altos e os acidentes, as enfermidades, físicas e psicológicas em decorrência do trabalho, eram muito comuns, já que o patronato permanecia indiferente, não fornecendo quaisquer equipamentos de prevenção ou proteção (CASSAR, 2017, p. 11-12).

A esse respeito, o autor britânico Edward Palmer Thompson (1987) escreveu sobre os trabalhadores daquela época:

\footnotetext{
Um operário pode ser facilmente reconhecido quando caminha pelas ruas. Algumas de suas juntas provavelmente estarão afetadas. Se as suas pernas não forem tortas, terá os tornozelos inchados ou um ombro mais baixo que outro, ou os ombros projetados para frente. Ou qualquer outra deformação (THOMPSON apud NASCIMENTO; VIEGAS, 2016, p. 109).
}

Diante dessas consequências nocivas e após uma série de movimentos sociais obreiros, intensificaram-se as ideias protecionistas e intervencionistas, até que, finalmente, o Estado deixou a sua apatia, até então natural e comum, e passou a intervir nos contratos para o fim de restringir, em nome de uma maior justiça no relacionamento capital-trabalho, a autonomia da vontade privada (GOMES, 2003, p. 116). 
No Brasil, a primeira norma destinada a regular o processo de acumulação data de 1919 e reconhecia a obrigação do empregador em indenizar o operário em casos de doenças e acidentes do trabalho (LUCA, 2003, p. 473).

Tratava-se de uma regra de suma relevância social, à medida que se prestou a salvaguardar a saúde, a segurança, a integridade física e, até mesmo, a própria vida do trabalhador, que, como exposto alhures, era substancialmente ignorada e descartada pelo capital, o que justificou a necessidade e a prioridade de sua redação quando comparada às demais normas de proteção.

Surgiu, pois, desde logo assumindo caráter eminentemente preventivo e pedagógico para, sob a "ameaça" de se ter de desembolsar dinheiro em favor do trabalhador, temperar e limitar os instintos de avareza e de abuso do poder daqueles ligados à propriedade e voltados a explorar os mais fracos por meio da prestação de serviços (GOMES, 2003, p. 115).

A partir de então, o empregador passou a assumir a responsabilidade de proporcionar aos seus empregados e trabalhadores um meio ambiente de trabalho higiênico e saudável. Porém, ainda hoje persiste a forte tendência de predominância do capitalismo perverso que aniquila a dignidade do hipossuficiente, o que configura a existência de inúmeros postos de trabalho insalubres, a despeito da possibilidade de sua neutralização e/ou eliminação. Tudo isso pelo simples fato de ser economicamente mais vantajoso para o empregador a inobservância das normas de saúde e segurança do trabalho, seja em virtude da deficitária fiscalização do Ministério do Trabalho e Emprego; do improvável ingresso do trabalhador perante a justiça do trabalho para demandar suas verbas indenizatórias - quanto mais com a vigência da Reforma Trabalhista - ou, quando pagas, por se tratar de valores significativamente inferiores aos que seriam despendidos com os devidos aparelhos e procedimentos de contenção do risco.

Não obstante, malgrado a presença dessas e outras truculências, em algumas atividades, dadas as suas peculiaridades, o trabalhador acaba sendo exposto a agentes ou condições que colocam à prova a sua integridade física, independentemente da responsabilidade do empregador. Tratam-se de ocupações muitas vezes essenciais e que, de modo algum, podem ser ignoradas, entre elas, o trabalho em ambiente hospitalar.

De acordo com o artigo 189 da CLT, por atividades ou operações insalubres, pode-se compreender aquelas que, por sua natureza, condições ou métodos de trabalho, exponham os empregados a agentes nocivos à saúde, acima dos limites de tolerância fixados em razão da natureza e da intensidade do agente e do tempo de exposição aos seus efeitos.

Tais condições de trabalho insalubres se encontram, mais precisamente, na Norma Regulamentadora (NR) no. 15, da Portaria $n^{\circ}$. 3.214/1978 do Ministério do Trabalho, que aponta os agentes químicos, físicos e biológicos prejudiciais à saúde do trabalhador e estabelece os limites de tolerância do organismo a essas agressões. Nesse aspecto, pode-se dizer que entre as atividades insalubres listadas pela NR $n^{\circ} .15$ encontram-se aquelas relativas a ruído, seja contínuo, intermitente ou de impacto; calor; radiações ionizantes; condições hiperbáricas; radiações não ionizantes; vibrações; frio, umidade; agentes químicos cuja insalubridade é caracterizada por limite de tolerância e inspeção no local de trabalho; poeiras minerais e agentes biológicos. Esses são, pois, os principais agentes nocivos capazes de degenerar a saúde e a vida do trabalhador (CASSAR, 2017, p. 809). 
Diante de tal situação, o legislador estabeleceu normas que visam minimizar esse quadro que, ao menos em regra, haveria de ser excepcional. Desse modo, não só indenizando a morte ou a incidência de enfermidades do trabalho, como também estipulando adicionais mensais em "compensação" à exposição do obreiro a tais agentes, além de uma regulamentação que tem por escopo eliminar ou neutralizar as nocividades. Instituíram-se, também, normas de cunho previdenciário, cuja finalidade é a concessão de uma espécie de aposentadoria especial, a ser deferida de modo antecipado ao trabalhador, afastando-o, o quanto antes, daquelas condições degradantes. Tais diretrizes foram estabelecidas a fim de que não sejam ainda mais comprimidas as suas expectativas de longevidade e qualidade de vida, consagrando, assim, a proteção à saúde, elemento indispensável para o alcance e manutenção de uma existência digna.

Nesse sentido, adiantando-se um pouco na história, a Constituição de 1988, em seu artigo 196, determina como direito de todos e dever do Estado a saúde, e estabelece em seu artigo $6^{\circ}$. que esta é um direito social fundamental, de acesso universal e igualitário. As normas relativas à saúde passam, então, a assumir status de ordem pública e, portanto, inderrogáveis e inafastáveis pela vontade das partes (CASSAR, 2017, p. 812).

A Convenção $n^{\circ} .148$ da Organização Internacional do Trabalho (OIT), que trata da proteção dos trabalhadores contra os riscos profissionais devidos à contaminação do ar, ao ruído e às vibrações no local de trabalho também foi ratificada pelo Brasil em 1986. Já a Convenção de $\mathrm{n}^{\circ}$. 155 do mesmo órgão internacional, que versa sobre a segurança e saúde dos trabalhadores e o meio ambiente de trabalho, foi ratificada em 1994, por meio do Decreto de $n^{\circ}$. 1.254/94.

Convém dizer que o direito social à previdência também foi conquistado a fim de resguardar a saúde e o bem-estar daquele que trabalhara durante o estado de caos social instaurado perante a inércia do Estado investido na fórmula do laissez faire, laissez passer. ${ }^{1}$

Assim, conforme se observa o direito do trabalho, a saúde e a previdência encontram-se mútua e intrinsecamente ligadas, desde o seu nascedouro, enquanto direitos de segunda geração, cujo objetivo máximo consiste na promoção efetiva da dignidade do indivíduo enquanto pessoa humana.

Com efeito, ainda em tempos remotos, Immanuel Kant já definia a dignidade da pessoa humana como fim e não como meio. Em sua concepção, o "outro" deveria ser compreendido não como mero objeto, mas sim como sujeito, tratado como fim em si mesmo, de forma a celebrar não somente a sua dimensão individual, mas também social (KANT, 1980, p. 139-140).

Esse imperativo, de acordo com Dinaura Godinho Pimentel Gomes (2003, p. 96), estabelece que "[...] todo homem, aliás, todo ser racional, como fim em si mesmo, possui um valor não relativo - como é por exemplo, um preço, - mas intrínseco, isto é, a dignidade".

Essa assertiva é ainda oportuna nos dias de hoje, no sentido de chamar à reflexão para o valor da pessoa humana, como ser social, como valor fonte de todos os valores, desconstruindo, assim, toda linha de pensamento voltada a qualquer tendência de coisificação ou instrumentalização do ser humano (GOMES, 2003, p. 96).

Expressão francesa muito utilizada no período do liberalismo econômico para designar que o mercado deve funcionar livremente, sem a interferência do Estado e que, basicamente, significa "deixai fazer, deixai ir, deixai passar". (Trad. do autor.) 
Felizmente, essa exigência de observância e reconhecimento da dignidade da pessoa humana ocupa lugar de relevo atualmente, tanto no pensamento político quanto no jurídico e filosófico, o que tem levado a considerar tal princípio como pedra angular de toda ordem jurídica e interpretação normativa, ao menos em tese (GOMES, 2003, p. 96-97).

Deve-se ressaltar, no entanto, que a dignidade da pessoa humana não é, nem nunca foi, uma criação normativa, mas antes um valor inerente à própria natureza humana, e que, portanto, preexiste a toda experiência especulativa (GOMES, 2003, p. 98).

Todavia, apesar desse importante elemento norteador ser exaustivamente reconhecido e discursado no plano teórico, em termos práticos, com frequência nos deparamos com leis e decisões judiciais que o ignoram e contradizem por completo, rebaixando a pessoa humana à condição de uma simples coisa, com dignidade e bem-estar passíveis de monetização.

\section{Monetização de RISCOS}

O artigo 192 da CLT, no intento de monetizar a saúde do empregado em detrimento da eliminação ou redução do risco, até mesmo porque na grande maioria das vezes estes não podem ser eliminados por completo, estabelece que o trabalho realizado em áreas insalubres será remunerado com um adicional de $40 \%, 20 \%$ ou $10 \%$ dependendo do grau de nocividade em que se enquadre, tendo como base de cálculo o salário mínimo da região.

A base de cálculo do referido adicional não será objeto de análise e discussão no presente estudo, no entanto, é preciso mencionar que é bastante questionável, uma vez que a Carta Magna de 1988 preceitua, em seu artigo $7^{\circ}$., IV, a impossibilidade de vinculação do salário mínimo para qualquer fim, o que já foi exaustivamente discutido pela doutrina e jurisprudência, mas, até hoje, não se chegou a lugar algum.

O fato é que, quando a lei determina que o empregador pague o adicional de insalubridade, acaba por permitir a venda, por ínfimos valores, da saúde do trabalhador, monetizando um risco ao qual de modo algum se poderia atribuir um preço.

De acordo com Carolina de Souza Novaes Gomes Teixeira e Lucas Scarpelli de Carvalho Alacoque (2013, p. 342), entende-se por monetização ou monetarização dos riscos “[...] a política de aumento da remuneração do trabalhador que está exposto a agentes agressivos, em razão da possibilidade da ocorrência de acidente do trabalho ou desenvolvimento de doença ocupacional".

Trata-se, na verdade, de uma das previsões legislativas mais bárbaras e absurdas já feitas, uma vez que, de certa forma, resta por dispensar a necessidade de controle e eliminação do agente nocivo à medida que "recompensa" financeiramente aquele que labora em condições de risco à própria integridade física, recompensa essa que acaba por tornar ainda mais atrativa a manutenção do trabalho gravoso, visto que é substancialmente diminuta se comparada às despesas próprias da prevenção.

É certo que algumas atividades, conforme já foi exposto, comportam riscos à saúde e à segurança do trabalhador de impossível eliminação e, ainda assim, não podem ser extintas, por se tratar de serviços de grande relevância social. Para esses casos, entende-se que de modo algum se pode responsabilizar o empregador, desde que este proceda da melhor ma- 
neira para neutralizar o risco, hipóteses em que, inclusive, entende-se crível o pagamento do adicional em questão.

Todavia, o que se tem visto rotineiramente é uma monetização dos riscos deliberada e irrestrita, sobrepondo-se ao que deveria ser o mais importante, a saúde do obreiro. Criaram-se mecanismos para conviver com o mal, e não para cortá-lo pela raiz. O adicional, indubitavelmente, significa a venda da saúde ou da própria vida do trabalhador, daí o rótulo que vem recebendo pela doutrina de adicional do suicídio ou da morte (TEIXEIRA; ALACOQUE, 2013, p. 342).

Diante dessas circunstâncias, é preciso perscrutar soluções para que cada atividade tenha seus riscos eliminados ou reduzidos ao máximo e que a monetização não prevaleça em detrimento da efetiva proteção à saúde do trabalhador. A aposentadoria especial tem sido uma dessas alternativas de conter os efeitos da monetização, afastando o trabalhador do risco antes que seja tarde demais. Com efeito, enquanto o dinheiro se sobrepuser às pessoas e a contínua prática de atividades insalubres não for extirpada - com exceção, óbvio, daquelas de cunho essencial -, a aposentadoria especial será mais que necessária, conforme se propõe expor adiante.

\section{A APOSENTADORIA ESPECIAL ENQUANTO INSTRUMENTO DE ATENUAÇÃO DOS EFEITOS DA MONETIZAÇÃO DE RISCOS - NORMAS REGULAMENTADORAS}

Regulamentada pelos artigos 57 e 58 da Lei no ${ }^{\circ} .8 .213 / 1991$, pelos artigos 64 a 70 do Decreto 3.048/1999 e pelos artigos 19 e 21 da Emenda Constitucional de no .103 de 12 de novembro de 2019, a aposentadoria especial consiste em uma espécie de benefício previdenciário concedido àqueles segurados que laboraram expostos a agentes nocivos à saúde ou à integridade física, sejam eles químicos, físicos ou biológicos, ou ainda, produto da associação de tais agentes presentes no ambiente de trabalho e no processo produtivo, em nível de concentração superior aos limites de tolerância estabelecidos durante quinze, vinte ou 25 anos, somados à idade mínima de 55, 58 e 60 anos, respectivamente, conforme o maior grau de lesividade da atividade e/ou exposição, nos termos da nova legislação da Reforma da Previdência.

A aposentadoria especial foi inaugurada com o advento da Lei Orgânica da Previdência Social (Lei 3.807/1960) e desde os seus primórdios carregou a finalidade precípua de proteger o trabalhador, afastando-o daquelas condições de trabalho prejudiciais à saúde de modo substancialmente precedente se comparado às demais modalidades de aposentadoria destinadas a trabalhadores que atuassem em condições comuns.

Isso se deu pelo fato de que a contínua e permanente exposição do trabalhador a agentes nocivos estava a deteriorar paulatinamente a saúde e a integridade física do obreiro, algo que vinha ocorrendo de modo tão cruel, que poucos ou mesmo quaisquer sinais eram exibidos com o passar dos anos, mas, ainda assim, o agente lesivo estava lá, presente, operando pouco a pouco até que, quando a enfermidade vinha a manifestar-se, já havia atingido proporções imensas, por vezes irreversíveis, chegando a desencadear moléstias de extrema gravidade, como o câncer, problemas respiratórios e circulatórios, perda da capacidade motora, osteoporose, hipertensão, problemas cerebrais e gastrointestinais etc. 
Assim, considerando tais consequências lastimáveis oriundas da exposição do segurado a agentes insalubres, o legislador, procurando resolver o problema, ou, ao menos, atenuar os seus efeitos, criou a aposentadoria especial para retirar o trabalhador daquelas situações de risco antes que a sua exposição o conduza a um estado fatal, tendo em vista o significativo mal já acometido à sua saúde em razão de tais condições de trabalho, mesmo que não tenha sido ainda manifesto, posto que já fora amplamente comprovada a agressividade de tais agentes, não somente em caráter científico, mas também social, dadas as largas experiências pregressas.

Diante disso, é perfeitamente passível de presunção a lesividade oriunda de trabalhos executados em ambientes insalubres, desde que se encontrem acima dos limites de tolerância para os agentes especiais previstos no Anexo IV do Decreto 3.048/1999, cujo rol é fechado.

Ademais, convém ressaltar que a aposentadoria especial não tem apenas a finalidade de amenizar os efeitos destrutivos do trabalho insalubre, mas também de prevenir a ocorrência desse tipo de trabalho.

De acordo com o $\S 6^{\circ}$., do artigo 57, da Lei 8.213/1991, o benefício será financiado com os recursos provenientes da contribuição patronal junto ao SAT (Seguro de Acidente do Trabalho) prevista no artigo 22, II, da Lei 8.212/1991, cujas alíquotas serão acrescidas de doze, nove ou seis pontos percentuais sobre a remuneração do trabalhador, conforme a atividade exercida pelo segurado a serviço da empresa permita a aposentadoria após quinze, vinte ou 25 anos respectivamente. Obviamente, o custeio dessa modalidade de aposentadoria recai sobre o empregador, o que o incentiva a eliminar cada vez mais os agentes insalubres de seus postos de trabalho, visto que atividades salubres não ensejam esse tipo de ônus, aumentando, portanto, o lucro da empresa.

Convém dizer que a esmagadora maioria das atividades especiais prevê a aposentadoria com 25 anos de contribuição e 60 anos de idade, com exceção do tempo especial em mineração subterrânea, cujas atividades sejam desenvolvidas afastadas das frentes de produção e da exposição aos asbestos e amianto, que demandam vinte anos de contribuição e 58 anos de idade. Já as atividades permanentes no subsolo de minerações subterrâneas em frentes de produção farão que os trabalhadores se aposentem com apenas quinze anos de contribuição e 55 anos de idade, dado o significativo dano à saúde.

Inobstante, a presença de agentes nocivos reconhecidamente cancerígenos em humanos, listados pelo Ministério do Trabalho, será suficiente para a comprovação da efetiva exposição do trabalhador (AMADO, 2017, p. 435).

Porém, nos demais casos, a comprovação da exposição do segurado a agentes nocivos se dará mediante a apresentação de um formulário preenchido pela empresa ou por seu preposto, com base em laudo técnico de condições ambientais de trabalho, expedido por médico do trabalho ou engenheiro de segurança do trabalho, considerando a classificação dos agentes nocivos e os limites de tolerância estabelecidos pela legislação trabalhista, bem como, a metodologia e os procedimentos de avaliação estabelecidos pela Fundação Jorge Duprat Figueiredo de Segurança e Medicina do Trabalho - FUNDACENTRO (AMADO, 2017, p. 442).

Desde $1^{\circ}$. de janeiro de 2004, esse formulário utilizado pela legislação previdenciária tem sido o Perfil Profissiográfico Previdenciário - PPP - assim considerado enquanto o do- 
cumento histórico-laboral do trabalhador, conforme modelo previamente estabelecido pelo Instituto Nacional do Seguro Social, que, entre outras informações, deverá conter as atividades desenvolvidas pelo obreiro, o resultado das avaliações ambientais e biológicas, o nome dos responsáveis por tais avaliações e outros dados administrativos correspondentes.

Por ocasião da cessação da prestação de serviços, o PPP deverá ser impresso em cópia autêntica e entregue atualizado em até trinta dias ao trabalhador, sob pena de multa.

Todavia, dado o lamentável caráter simbólico de grande parte da legislação garantidora de direitos sociais por uma série de fatores, entre eles a deficitária fiscalização, com o direito previdenciário não poderia ser diferente. Apesar das penalidades legais, o que se tem, na realidade, são inúmeras empresas emitindo Perfis Profissiográficos Previdenciários em desacordo com os laudos técnicos de condições ambientais de trabalho ou com base em laudos falsos, a fim de burlar a legislação, contorcendo a veracidade de documentos para não cumprir com sua responsabilidade em arcar com o adicional de insalubridade, assim como, com a alíquota de contribuição previdenciária mais alta, cujo prejuízo recai, exclusivamente, na pessoa do obreiro, que precisa, necessariamente, daquele formulário para aposentar-se, o que é passível de grande crítica, pois é sabido que a grande maioria das pessoas acaba deixando seu direito de lado, isso quando o conhecem e, por conseguinte, elas deixam de ajuizar as ações judiciais cabíveis para resguardá-lo. Ademais, mesmo quando o fazem, ainda se deparam com outros obstáculos ao alcance daquele tão necessário descanso, muitas vezes, criados até pelo próprio poder judiciário, que demanda provas de eficácia bastante incerta, conforme se verá adiante.

Outra crítica, cuja menção se faz pertinente, refere-se à exigência de ter o segurado laborado mediante exposição permanente aos agentes nocivos, pois é de notório conhecimento que a exposição meramente intermitente também é capaz de causar males à integridade física, o que já foi reconhecido, inclusive, em âmbito trabalhista por meio da Súmula 47 do Tribunal Superior do Trabalho, muito embora a legislação previdenciária insista em negar.

Contudo, apesar dessas e de outras dificuldades, a legislação é ainda benéfica ao segurado, visto que traz diversas disposições de cunho essencialmente protetivo e uma delas se encontra no artigo $3^{\circ}$. da Lei $10.666 / 2003$, que dispõe que a perda da qualidade de segurado não será considerada para fins de concessão da aposentadoria especial, desde que alcançados os devidos requisitos. Assim, uma vez completos o tempo de contribuição especial, a idade e a carência, o benefício será concedido desde a data de entrada do requerimento junto ao INSS. No caso de segurado empregado, no entanto, o benefício será concedido desde a data do desligamento do emprego, se requerido em até noventa dias daquela data (AMADO, 2017, p. 439).

Tamanha é a relevância do instituto que inexiste distinção entre homens e mulheres, sendo a renda mensal inicial correspondente a $100 \%$ do salário de benefício, não incidindo o fator previdenciário.

Quanto ao tempo de contagem especial para a aludida concessão, de acordo com o parágrafo único do artigo 65, do Decreto 3.048/1999, serão também considerados os períodos de descanso determinados pela legislação trabalhista, inclusive férias, àqueles decorrentes de afastamento por auxílio-doença ou aposentadoria por invalidez acidentários, bem como, 
os de percepção de salário-maternidade, desde que, à data do afastamento, o segurado esteja exposto aos fatores de risco.

Por todo o exposto, resta claro que a principal razão de ser da aposentadoria especial não é outra senão a efetiva proteção à saúde e à segurança do obreiro face às mazelas oriundas de uma monetização da vida exacerbada e irresponsável, em uma tentativa razoável de conter seus efeitos buscando desestimular a manutenção de tais condições com a incidência de alíquotas de contribuição mais altas, o que, ainda assim, não tem surtido tanto êxito, mas ao menos, chega a afastar o trabalhador mais cedo de tais barbaridades, impedindo que sua saúde, já substancialmente depravada, permaneça sendo comprada com o passar dos anos e, por conseguinte, se degrade ainda mais.

O cerne da proteção é justamente a dignidade do obreiro enquanto pessoa humana, portador de uma série de direitos inerentes à sua própria natureza, mas, principalmente e acima de tudo, detentor do direito a uma vida longínqua, sem pormenores sofrimentos advindos de moléstias que poderiam ter sido evitadas, capaz de desfrutar o convívio familiar e toda a afetividade que dispõe com uma gama de possibilidades, o que, de modo algum, seria consagrado não fossem as normas destinadas a restringir a crueldade advinda da autonomia privada das relações de capital que cuidam apenas de per si.

\section{O ARE 664.335}

Trata-se de agravo em recurso extraordinário interposto pelo Instituto Nacional do Seguro Social (INSS) contra decisão proferida pela Primeira Turma Recursal dos Juizados Especiais Federais de Santa Catarina sob o argumento de que a decisão recorrida restara por violar dispositivo da Constituição Federal - artigo102, III, alínea a.

O julgado contou com a presidência do Senhor Ministro Ricardo Lewandowski e a presença dos Senhores Ministros Celso de Mello, Marco Aurélio, Gilmar Mendes, Carmem Lúcia, Rosa Weber, Teori Zavascki, Roberto Barroso, e, como relator, o Senhor Ministro Luiz Fux.

A decisão objeto de recurso reconheceu o direito à aposentadoria especial por insalubridade de trabalhador que, embora exposto a ruído acima dos limites de tolerância, usara equipamento de proteção individual (EPI) supostamente eficaz a neutralizar ou eliminar o agente nocivo, conforme declaração do empregador no âmbito do perfil profissiográfico previdenciário (PPP).

Para fins de fundamentação, a referida decisão se utilizou do entendimento contido na Súmula 09 da Turma Nacional de Uniformização dos Juizados Especiais Federais (TNU), segundo a qual "o uso de equipamento de proteção individual (EPI), ainda que elimine a insalubridade, no caso de exposição a ruído, não descaracteriza o tempo de serviço especial prestado" (BRASIL, 2003).

Nesse contexto, inconformado com a decisão publicada, alegou o INSS em sede de recurso extraordinário que o reconhecimento do direito à aposentadoria especial a trabalhador que, conforme declarado pelo empregador em perfil profissiográfico usara equipamento eficaz, restaria por violar os artigos $201, \S 1^{\circ}$. e $195, \S 5^{\circ}$. da Constituição. Declarou, portanto, que a aposentadoria especial fora concedida independentemente da efetiva exposição do trabalhador ao agente nocivo e que a aludida concessão do benefício se deu sem a correspondente fonte de custeio. 
Conforme se depreende da redação do artigo 201, § ${ }^{\circ}$., da CF/88:

\begin{abstract}
É vedada a adoção de requisitos e critérios diferenciados para a concessão de aposentadoria aos beneficiários do regime geral de previdência social, ressalvados os casos de atividades exercidas sob condições especiais que prejudiquem a saúde ou a integridade física e quando se tratar de segurados portadores de deficiência, nos termos definidos em lei complementar (BRASIL, 2016).
\end{abstract}

Segundo o INSS, o dispositivo retrocitado consiste em corolário do princípio da isonomia, não podendo, por conseguinte, ser admitida decisão que, a despeito da vedação do uso de critérios diferenciados para a concessão de aposentadoria assim o faz, concedendo benefício que não se enquadra na exceção constitucional, mais precisamente, à efetiva demonstração de que o labor foi prestado em condições especiais que prejudicam a saúde ou a integridade física.

Para a autarquia, como foi fornecido ao trabalhador equipamento de proteção individual considerado eficaz à neutralização do risco mediante declaração do empregador no âmbito do perfil profissiográfico previdenciário, não poderia ser reconhecido o direito à aposentadoria especial, pois essa só seria cabível naqueles casos em que se houvesse uma efetiva exposição do trabalhador aos agentes nocivos. Logo, se o EPI se mostrara eficaz a conter tal exposição, não haveria que se falar em aposentadoria especial, sob pena de se estar concedendo privilégio indevido face aos demais segurados, pois o labor nessas situações se equipara a qualquer trabalho em ambiente salubre.

Salienta, também, o INSS, que a aludida concessão viola o artigo $195, \S 5^{\circ}$., da CF/88, segundo o qual: "Nenhum benefício ou serviço da seguridade social poderá ser criado, majorado ou estendido sem a correspondente fonte de custeio total" (BRASIL, 2016).

É que, conforme o $\S 6^{\circ}$. do artigo 57, da Lei 8.213/1991, a aposentadoria especial é financiada com os recursos provenientes da contribuição patronal junto ao SAT Especial (Seguro de Acidente do Trabalho), cujas alíquotas variam de doze, nove ou seis pontos percentuais sobre a remuneração do trabalhador, conforme o grau de risco da atividade exercida. No entanto, ao criar o Fator Acidentário de Prevenção (FAP), o artigo 10 da Lei $n^{\circ}$. 10.666/03 concedeu redução de até $50 \%$ do valor da contribuição junto ao SAT em favor das empresas que tenham um bom desenvolvimento no tocante à respectiva atividade econômica no quesito relações e segurança do trabalho, o que foi interpretado administrativamente pelo INSS no sentido de conceder a isenção àquelas empresas que disponibilizam aos seus empregados equipamentos de proteção declarados eficazes nos formulários legalmente previstos. Logo, ao conceder tais equipamentos ao trabalhador, a empresa não contribuiu integralmente junto ao SAT, de modo que a aposentadoria especial ficara carente de fonte de custeio, viciando a isonomia no subsídio dos benefícios previdenciários.

Por sua vez, o recorrido e os diversos intervenientes que integraram o processo - Confederação Brasileira de Aposentados e Pensionistas (COBAP); União; Instituto Brasileiro de Direito Previdenciário (IBDP); Sindicato dos Trabalhadores nas Indústrias Siderúrgicas, Metalúrgicas, Mecânicas, de Material Elétrico e Eletrônico e Indústria Naval de Cubatão, Santos, S. Vicente, Guarujá, Praia Grande, Bertioga, Mongaguá, Itanhaém, Peruíbe e S. Sebastião; Sindicato dos Trabalhadores no Comércio de Minérios, Derivados de Petróleo 
e Combustíveis de Santos e Região e Sindicato dos Trabalhadores nas Indústrias do Papel, Papelão e Cortiça de Mogi das Cruzes, Suzano, Poá e Ferraz de Vasconcelos - aludem que o direito à aposentadoria especial não depende da efetiva exposição do trabalhador ao agente nocivo, bastando a sua presença no ambiente de trabalho acima dos limites de tolerância legalmente permitidos. Em outros termos, insistem que o uso dos EPIs, ainda que venham a neutralizar os agentes nocivos, não pode prejudicar a aposentadoria especial, uma vez que o local de trabalho continua insalubre, sendo esse o requisito constitucionalmente previsto.

Destacam, também, a impossibilidade física de equipamentos de proteção individual eliminarem por completo o prejuízo à saúde e à segurança do trabalhador que advém do puro e simples labor em ambiente insalubre.

Nesse sentido, a Procuradoria-Geral da República, quando intimada, manifestou-se pelo desprovimento do recurso, em parecer que porta a seguinte ementa:

Recurso Extraordinário. Aposentadoria Especial. Caráter social e protetivo. Equipamento de Proteção Individual (EPI). Eficácia questionável. Direitos à vida, à saúde e à previdência social. Dignidade da pessoa humana. Fonte de custeio não comprometida pela concessão de incentivo previsto no art. $22, \S 3^{\circ}$., da Lei $\mathrm{n}^{\circ}$. 8.212/91. Pelo desprovimento da iniciativa (BRASIL, 2014, p. 10).

Especificamente em relação ao ruído, agente nocivo em questão no caso concreto, mencionaram uma série de variáveis que viciam a eficácia do equipamento de proteção individual, entre elas, a inadequabilidade de um protetor auricular padrão à forma do ouvido do obreiro, intensidade do som, higiene, tempo e forma de uso etc.

Ressaltaram, também, que, no caso específico, o ruído entra não só pelas vias auditivas, mas também pela via óssea, em virtude da vibração mecânica de ossos, cartilagens e músculos do esqueleto craniano que sua exposição impulsiona, causando danos não apenas à audição, mas também cardiovasculares, digestivos e psicológicos.

Por fim, quanto ao argumento da criação de benefício sem a correspondente fonte de custeio, alegaram que a isenção parcial do SAT concedida àquelas empresas que simplesmente declaram fornecer equipamentos de proteção individual a seus trabalhadores é de total responsabilidade administrativa, pois produto de simples interpretação legal equivocada da autarquia, não podendo o trabalhador que prestou serviços em ambiente nocivo sofrer as consequências disso.

Diante desse quadro, preliminarmente, o Tribunal, por unanimidade, deu provimento ao agravo para o processamento do recurso extraordinário, reconhecendo sua repercussão geral sob o fundamento de ser matéria de densidade constitucional, já que se trata de ofensa ao direito fundamental à previdência social (art. 201, CF/88), com reflexos imediatos nos cânones do direito à vida (art. $5^{\circ}$., caput, CF/88), à saúde (arts. $3^{\circ}$., $5^{\circ}$., e 196, CF/88), à dignidade da pessoa humana (art. $1^{\circ}$., III, CF/88), e ao meio ambiente de trabalho equilibrado (arts. 193, e 225, CF/88), o que revelaria a importância do tema tanto do ponto de vista econômico e social, como também político e jurídico.

A seguir, proferiu antecipadamente o voto o Senhor Ministro Relator Luiz Fux, dando provimento ao recurso do INSS, pelo que fixou uma tese segundo a qual: 
[...] A utilização de equipamento de proteção individual - EPI, que neutralize e elimine ou reduza a nocividade dos agentes, comprovada mediante formulário, consoante a legislação previdenciária, não configura tempo de serviço especial para fins de concessão da aposentadoria especial (BRASIL, 2014, p. 83).

Em outras palavras, quis o Ministro em comento dizer que a pura e simples disponibilização do equipamento de proteção individual por parte da empresa ao trabalhador, mediante comprovação em perfil profissiográfico previdenciário, é capaz de eliminar o caráter nocivo da atividade. Logo, em sua concepção, já que comprovado no caso concreto por meio do PPP que fora fornecido ao segurado - protetor auricular para neutralizar o ruído não haveria que se falar em direito à aposentadoria especial.

Entendeu que, à luz do artigo 201, $\S 1^{\circ}$. da CF/88, a melhor interpretação seria aquela que contempla a aposentadoria especial enquanto um benefício excepcional, destinado ao segurado que efetivamente exerceu suas atividades laborativas em condições especiais que prejudiquem a saúde ou a integridade física, assim compreendido enquanto àquele trabalhador que laborou em ambiente insalubre desprovido de equipamentos de proteção, o que seria demonstrado mediante o PPP, conforme determina o artigo 58, $\S 1^{\circ}$. da Lei 8.213/91.

Não obstante, alegou, também, ser aquela linha de defesa arguida pelo recorrido dotada de uma proteção para além de exacerbada, já que acreditava que o caráter nocivo da atividade se dá mediante a relação direta do trabalhador com o agente insalubre e não por meio de uma exposição em potencial àquele agente.

Por último, quanto à questão de violação ao artigo $195, \S 5^{\circ}$., da $\mathrm{CF} / 88$, considerou que não há ofensa ao princípio da preservação do equilíbrio financeiro e atuarial. Para tanto, justificou que existe previsão na própria sistemática da aposentadoria especial da figura do incentivo (art. 22, II e $\S 3^{\circ}$., Lei $n^{\circ}$. 8.212/91), que, por si só, não consubstanciaria a concessão de benefício sem a correspondente fonte de custeio.

Ademais, alegou, também, que a jurisprudência do Supremo Tribunal Federal considera que o artigo $195, \S 5^{\circ}$., da $\mathrm{CF} / 88$, contém norma dirigida ao legislador ordinário, disposição inexigível quando se trata de norma criada pela própria Constituição, principalmente em se tratando de um direito fundamental, que corresponde à norma de eficácia plena, direta, imediata e integral.

Posteriormente, passando a palavra ao Senhor Ministro Roberto Barroso, proferiu, ele, voto, após ter vista aos autos, negando provimento ao recurso do INSS de modo a conceder a aposentadoria especial ao segurado no caso concreto.

Para tanto, estabeleceu duas teses em sede de repercussão geral:

1. O direito à aposentadoria especial pressupõe a efetiva exposição do trabalhador a agente nocivo à sua saúde, de modo que, se o EPI for realmente capaz de neutralizar a nocividade não haverá respaldo constitucional à aposentadoria especial.

2. Na hipótese de exposição do trabalhador a ruído acima dos limites legais de tolerância, a declaração do empregador, no âmbito do Perfil Profissiográfico Previdenciário (PPP), no sentido da eficácia do Equipamento de Proteção Individual - EPI, não descaracteriza o tempo de serviço especial para aposentadoria (BRASIL, p. 82). 
Na primeira tese, buscou o Ministro dar interpretação ao artigo 201, §1 ${ }^{\circ}$., da CF/88, em sentido análogo àquela dada pelo Senhor Ministro Luiz Fux. Segundo Barroso, o direito à aposentadoria especial pressupõe uma exposição direta entre o segurado e o agente nocivo, de modo que, havendo EPI eficaz a conter o dano, não haverá que se falar na aludida aposentadoria.

Todavia, em relação ao agente específico ruído, razão pela qual firma a segunda tese, após longos estudos doutrinários e científicos, chega-se à conclusão de que realmente não existe, até os dias atuais, aparelho de proteção individual capaz de conter por completo a sua nocividade, motivo pelo qual discorre que, ainda que declarada a sua eficácia pelo empregador, não se pode elidir a contagem de tempo especial para fins de aposentadoria.

Ocorre que, conforme fora observado pelo recorrido, igualmente constatou o Ministro Barroso que o ruído não gera apenas consequências auditivas, mas também extra-auditivas, adentrando no organismo mediante vibrações transferidas pelo tecido ósseo, o que EPI nenhum é capaz de conter.

Para além, observou ainda Barroso que a exposição ao ruído pode ocasionar uma série de moléstias que, inclusive, poderão acompanhar o restante da vida do trabalhador, entre elas o surgimento do zumbido que importa em distúrbios do sono, alterações na esfera neurovegetativa, fadiga, ansiedade, problemas gastrointestinais, cardiovasculares e hormonais, cansaço crônico, irritabilidade, déficit de atenção etc.

Por fim, também ressalta que calor, barba, tamanho e formato do ouvido, erro de posicionamento, manutenção e trocas inadequadas, sujeira, tempo de uso efetivo, nível do ruído e até mesmo o uso de outros EPIs, entre outros fatores, afetam substancialmente a efetividade do aparelho na contenção do agente nocivo.

Nesse viés, demonstra a existência de uma diferença gritante entre os valores de atenuação medidos em laboratórios de certificação e aqueles medidos no campo, cerca de $40 \%$ a 60\% mais baixos. Diante disso, conclui que o Certificado de Aprovação (CA) conferido aos aparelhos pelo Ministério do Trabalho, muito embora venha a obedecer a especificações internacionais, não é suficiente para atribuir a presunção de eficácia aos EPIs, pelo menos, não no caso do agente nocivo ruído.

Encerra, portanto, que negar o direito à aposentadoria especial a trabalhadores expostos a ruído pela mera utilização de EPI, cuja eficácia real é de impossível comprobação, seria o mesmo que negar o acesso ao benefício a trabalhadores efetivamente expostos ao agente nocivo, importando, aí sim, em violação ao artigo $201, \S 1^{\circ}$. da CF/88.

Em relação à suposta violação ao artigo $195, \S 5^{\circ}$. da $\mathrm{CF} / 88$, corroborou Barroso ao entendimento de Fux, acrescentando apenas que há fonte de custeio para o direito à aposentadoria especial para além da contribuição junto ao SAT, quais sejam, os instrumentos tradicionais de financiamento da previdência social - recursos provenientes dos orçamentos dos entes federativos e contribuições sociais pagas pelo empregador e pelo segurado, razão pela qual não haveria que se falar em ausência de fonte custeio para a concessão do benefício.

Por conseguinte, uma vez proferido o aludido voto, retomou a palavra o Senhor Ministro Luiz Fux e retificou seu posicionamento, concordando com a exposição do Ministro Barroso a respeito da ineficácia dos EPIs na contenção do agente nocivo ruído, pelo que negou provimento ao recurso e aderiu às duas teses sugeridas pelo aludido ministro. 
O Senhor Ministro Marco Aurélio, por sua vez, também negou provimento ao recurso sob o fundamento de ser fato notório que não se tem, no cenário atual, equipamento de proteção individual capaz de afastar os reflexos nocivos do barulho ao organismo. No entanto, refutou ambas as teses propostas, atendo-se ao caso concreto.

Segundo ele, não seria crível alterar matéria já pacificada nos Juizados Especiais, inclusive mediante enunciados de súmula, o que revela torrenciais pronunciamentos a respeito. Ademais, argumenta, também, que considerada a boa política judiciária, não é aconselhável suscitar a apuração da eficácia do equipamento, posto que ocasionaria o deslocamento das ações dos Juizados Especiais que não comportam espaço para implementar-se perícia ou discussão maior quanto a elementos probatórios, contribuindo ainda mais para a morosidade dessas ações.

Alude, igualmente, que estariam os demais ministros sobremodo preocupados com a questão auditiva e olvidando-se que aquele que presta serviços por longa data, utilizando-se de equipamento de proteção trabalha, sim, em condições especiais.

Para o ministro, a Constituição Federal no artigo 201, $\S 1^{\circ}$. traz à baila dualidade. Há a referência a condições que coloquem em risco a saúde do trabalhador, mas também a sua integridade física, sendo que o simples uso de EPI já é incômodo, o que, por si só, já provocaria impactos psicológicos e no organismo do obreiro, podendo desencadear outras doenças.

Por fim, ressalta a incongruência das teses objeto de repercussão geral, uma vez que, enquanto uma delas admite que o equipamento de segurança não afasta os efeitos nocivos, a outra, a um só tempo, afirma que, se o equipamento de segurança for eficaz, não há o direito à tomada do tempo de serviço enquanto especial.

Quanto ao Senhor Ministro Teori Zavascki, em seu tocante, buscou dar interpretação ao artigo 201, $\S 1^{\circ}$. da $\mathrm{CF} / 88$ semelhantemente àquela dada pelo Senhor Ministro Luiz Fux, de modo a refutar a Súmula de $n^{\circ} .09$ da TNU, ora alegada na decisão recorrida. Sustentou, portanto, que o entendimento manifesto na súmula haveria de ser reformado, pois estabelece que, embora o uso de EPI elimine a insalubridade, continua a computar-se aquele tempo de trabalho enquanto serviço especial, o que não se deseja, mas apenas naqueles casos em que a nocividade não seja eliminada.

Assim, inicialmente, deu provimento ao recurso por entender que a decisão recorrida estava fundamentada pura e simplesmente na Súmula $n^{\circ} .09$ da TNU e não em elementos probatórios. A seu ver, já que a súmula arguida dizia que ainda que se eliminasse a insalubridade, faria jus o trabalhador à aposentadoria especial, no caso concreto, a insalubridade fora eliminada e, por conseguinte, o recurso deveria ser deferido.

No entanto, após extensa discussão com os demais ministros, chegou à conclusão de que fora demonstrado, na fase instrutória, que no caso concreto o aparelho fora ineficaz, e, por essa razão, acabou negando provimento ao recurso.

Nesse cenário, Zavascki restou por aderir à primeira tese proposta pelo Ministro Barroso, mas se recusou, decididamente, em filiar-se à segunda. Para o ministro, a segunda tese não reflete questão constitucional, mas, de fato, o que juridicamente impossibilitaria a sua repercussão geral. Entendeu, por conseguinte, que a questão acerca da eficácia ou não do aparelho de proteção individual em eliminar o agente nocivo ruído é meramente uma interpelação fática, sobre a qual a técnica e a deliberação, em sede de repercussão geral, 
não interessa. A única questão de direito a ser discutida e fixada mediante tese seria, em sua concepção, aquela acerca de que, uma vez eficaz, o uso do equipamento de proteção individual eliminaria ou não o direito à aposentadoria especial, pelo que se posicionou a favor da exclusão.

Os demais ministros presentes, por seu turno, sem maiores ponderações, decidiram por negar provimento ao recurso do INSS, ao que manifestaram adesão às duas teses propostas pelo ministro Barroso, já citadas.

Assim, por unanimidade, o Tribunal negou provimento ao recurso extraordinário e, por maioria, vencido o ministro Marco Aurélio, assentou a tese segundo a qual o direito à aposentadoria especial pressupõe a efetiva exposição do trabalhador a agente nocivo à sua saúde, de modo que, se o Equipamento de Proteção Individual (EPI) for realmente capaz de neutralizar a nocividade, não haverá respaldo constitucional à aposentadoria especial. O Tribunal, também por maioria, vencidos os ministros Marco Aurélio e Teori Zavascki, assentou a tese de que, na hipótese de exposição do trabalhador a ruído acima dos limites legais de tolerância, a declaração do empregador, no âmbito do Perfil Profissiográfico Previdenciário (PPP), da eficácia do Equipamento de Proteção Individual (EPI), não descaracteriza o tempo de serviço especial para a aposentadoria. Dessa forma, deram encerramento.

\section{ELEMENTOS CRÍTICOS}

Apesar da extensa fundamentação, o ARE 664.335 é passível de contundentes críticas se submetido a uma análise sob a ótica da dignidade do segurado enquanto pessoa humana.

Com efeito, ao deliberarem sobre o tema, olvidaram-se os ministros de considerar a condição de hipossuficiente do trabalhador, atribuindo ao segurado o ônus de uma prova cuja legitimidade é bastante questionável, e, ainda assim, tornando-a requisito indispensável à concessão de um benefício tão necessário à conservação da saúde e da vida do obreiro.

Anteriormente, uma vez verificada a existência de condições especiais que prejudicassem a saúde ou a integridade física do trabalhador no ambiente e/ou métodos de trabalho acima dos limites de tolerância legalmente estabelecidos, o direito à aposentadoria especial costumava ser prontamente concedido, ainda que se houvesse a entrega e utilização de equipamento de proteção individual por parte da empresa ao trabalhador.

Tal entendimento fora pacificado, até mesmo, no âmbito previdenciário, não apenas nos termos da súmula de $n^{\circ} .09$ da Turma Nacional de Uniformização dos Juizados Especiais Federais já transcrita, mas também no enunciado nº 21 do Conselho de Recursos da Previdência Social, segundo o qual:

O simples fornecimento de equipamento de proteção individual de trabalho pelo empregador não exclui a hipótese de exposição do trabalhador aos agentes nocivos à saúde, devendo ser considerado todo o ambiente de trabalho (BRASIL, 1999).

Assim também caminhava a jurisprudência dos tribunais: 
PREVIDENCIÁRIO. AGRAVO INTERNO. APELAÇÃO CÍVEL. COMPROVAÇÃO TEMPO TRABALHADO. RECONHECIMENTO CONDIÇÕES ESPECIAIS. CONVERSÃO DO TEMPO DE SERVIÇO ESPECIAL EM COMUM. EPI NÃO DESCARACTERIZA INSALUBRIDADE. I - Os agentes químicos e o agente físico ruído, aos quais esteve exposto o autor no período de 22/06/1979 a 16/02/1983, 14/11/1983 a 08/02/1984, 02/07/1986 a 08/05/1996 e 02/11/1996 a 10/11/1997, encontram-se incluídos no rol exemplificativo de atividades profissionais consideradas insalubres, perigosas ou penosas, inserto no Decreto $n^{\circ} .53 .831 / 64$ (código 1.2.11 e 1.1.6, respectivamente), o que por si só basta para o deferimento do pedido de conversão do referido tempo de serviço, não sendo, pois, necessária a comprovação das condições especiais de trabalho. II - Os documentos apresentados pelo autor - laudos técnicos assinados por engenheiro de segurança do trabalho - não podem ser desprezados, pois, embora não se tratem de laudos judiciais, atendem à legislação em vigor, e atestam que o autor exercia atividade insalubre de forma habitual e permanente. III - Não há que se falar na neutralização dos agentes agressivos por uso de equipamento de proteção individual, vez que a utilização do equipamento de proteção não descaracteriza a atividade como especial. 1. O fato de a empresa fornecer ao empregado o EPI - Equipamento de Proteção Individual - e, ainda que tal equipamento seja devidamente utilizado, não afasta, de per se, o direito ao benefício da aposentadoria com a contagem de tempo especial, devendo cada caso ser apreciado em suas particularidades. (STJ. $5^{\text {a }}$ Turma. RESP: 584859. Relator: Ministro Arnaldo Esteves Lima. Data da Decisão: 18/08/2005. Pub: DJ, 05/09/2005, p. 458. IV - Agravo Interno não provido).

(TRF-2 - AGTAC: 277340 RJ 2001.02.01.047017-7, Relator: Desembargador Federal MESSOD AZULAY NETO, Data de Julgamento: 20/08/2008, SEGUNDA TURMA ESPECIALIZADA, Data de Publicação: DJU - Data: 01/09/2008 - Página: 449).

Todavia, o recurso do INSS trouxe à discussão os termos de tal consenso, ressaltando, como visto, a necessidade de uma exposição direta entre o trabalhador e o agente nocivo para a aquisição do direito à aposentadoria especial, ao que coube ao Supremo Tribunal Federal decidir em sede de repercussão geral.

Deliberou, portanto, o STF, que o direito à aposentadoria especial pressupõe a efetiva exposição do trabalhador a agente nocivo à sua saúde, de modo que, se o equipamento de proteção individual for capaz de neutralizar a nocividade, não haverá respaldo constitucional à aposentadoria especial.

Nota-se, que, a partir da aludida decisão, é ônus do segurado demonstrar não apenas o tempo de trabalho exercido em condições insalubres conforme dispõe o $\S 4^{\circ}$. do artigo 57 da Lei 8.213/91, mas também que, naqueles casos em que fora fornecido EPI, este não se demonstrou suficiente a eliminar o risco, partindo do pressuposto de que o mero uso desse tipo de equipamento já é bastante a desconfigurar a aposentadoria especial, o que demonstra evidente presunção desfavorável ao obreiro que, muitas vezes, apesar de ter sido efetivamente exposto a condições degradantes, não consegue se desincumbir daquele ônus.

Isso porque, os índices de insalubridade auferidos mediante perícia muitas vezes não refletem a verdade real dos fatos por uma série de circunstâncias. Entre elas, observa-se que o aparelho de proteção utilizado quando da realização de perícia é sempre um aparelho 
novo, e, por conseguinte, em perfeitas condições de uso, quando, na verdade, os aparelhos utilizados pelos trabalhadores são velhos, mal higienizados e posicionados, o que ocasiona, por si só, uma grande divergência entre os níveis de atenuação de risco, objeto de perícia face à realidade. Ademais, durante a perícia aquele aparelho é utilizado em sua individualidade, sem interferência com os demais, o que também implica nos valores de atenuação, sem mencionar o fato de que o trabalhador, ao longo da jornada, acaba por deixar de usar os aparelhos em determinado momento em virtude do incômodo que provocam, o que, uma vez aliado às exposições já advindas quando do efetivo uso, incorre em uma nocividade sem precedentes.

Nada disso é considerado em perícia, em que se parte de constatações meramente subjetivas para afirmar o geral, o que, de modo algum, pode ser considerado crível para expressar a verdade.

Ignora-se por completo a hipossuficiência do trabalhador enquanto parte mais frágil, conferindo a ele o ônus de produzir uma prova que, conforme mencionado alhures, difere substancialmente da realidade nas fábricas, fazendo que o trabalhador se torne o seu próprio verdugo.

Uma decisão efetivamente calcada nos valores da justiça deveria considerar como fator de presunção, ainda que relativa, a ineficácia dos aparelhos de proteção na contenção dos agentes nocivos, distribuindo o ônus da prova ao INSS, de modo que somente a demonstração de que o aparelho fora, de fato, plenamente suficiente a conter o risco autorizaria a negativa do benefício, e não o contrário. Até mesmo porque, o aludido órgão, por si só, já é repleto de peritos próprios, possuindo uma maior facilidade na produção da prova se comparado ao segurado que terá de contratar peritos assistentes.

Como se vê, estamos diante de uma distribuição do ônus da prova em desacordo com o artigo $373, \S 1^{\circ}$. do $\mathrm{CPC} / 15$, onde, a despeito da excessiva dificuldade do segurado em apresentar as mencionadas provas, insiste-se em delegar-lhe um ônus de eficácia variável e duvidosa.

Em "favor das contas públicas", a decisão presume que a simples utilização de um equipamento é capaz de afastar os demais direitos necessários à proteção à saúde do obreiro, sobrepondo as finanças em detrimento das pessoas, o que revela, desde logo, a perspectiva exclusivamente monetária do Tribunal.

Ademais, conforme fora muito bem exposto pelo Ministro Marco Aurélio em seu voto, se, de um lado, pode-se afirmar que, em se tratando do agente nocivo ruído, o devido e regular uso de equipamentos de proteção individual não é capaz de conter a agressão à saúde do trabalhador, como presumir que, de outro, demais equipamentos de proteção poderiam afastar a nocividade de outros agentes agressivos se não são experts na área?

Já dizia Barroso, no início de seu voto, ao propor a repercussão geral apenas ao agente específico ruído, que a tese principal exigiria que o Tribunal examinasse a eficácia do EPI na neutralização de todos os agentes nocivos à saúde do trabalhador, abordando todos aqueles previstos no rol da NR-15 do Ministério do Trabalho, o que apresentaria notável complexidade técnica concernente a ramos de conhecimento diversos do direito, de forma que, enquanto ministros, deveriam eles adotar uma postura de autocontenção no julgamento, sob pena de maximizar as chances de erro, tal como efetivamente aconteceu. 
Com efeito, é nítido o caráter contraditório e sem fundamento do acórdão, que, ao insistir em uma repercussão geral completamente desconexa ao caso concreto, restou por firmar teses contrárias e que se negam entre si.

Inobstante, conforme ensina Maria Helena Carreira Alvim Ribeiro, (2007, p. 292):

[...] Doutrinadores já se posicionaram no sentido de que o Equipamento de Proteção Individual - EPI, fornecido pelo empregador, não deve elidir o cômputo do tempo de serviço como especial, pois não é correta a conclusão de que o EPI reduz a exposição do trabalhador aos agentes nocivos, em razão da impossibilidade técnica de comprovação de sua eficácia real.

No mesmo sentido, Fábio Zambitte (2015, p. 627) leciona:

[...] No que diz respeito ao EPI, por exemplo, há crescente consenso sobre a sua insuficiência na proteção do trabalhador, haja vista a improvável utilização de equipamento durante toda a jornada, especialmente pela irritação e incômodo que provoca. Cada vez mais, conclui-se pela necessidade de proteção no maquinário (EPC), de forma a evitar ambientes inadequados de trabalho. O EPI seria, na verdade, a última opção e, mesmo assim, de eficácia duvidosa.

Para Wladimir Novaes Martinez (1998), o direito à aposentadoria especial dispensa, por parte do segurado, a prova do efetivo prejuízo físico, bastando a mera possibilidade de sua ocorrência, ou seja, a probabilidade do risco.

Airton Kwitko (2006) ainda adverte que confiar nas instruções ou no experimento do fabricante para estimar a atenuação do EPI em circunstâncias normais de uso, isto é, no mundo real, é extremamente arriscado. A razão mais óbvia para a pobre atenuação observada no plano efetivo é que os EPIs não são adequadamente escolhidos e/ou utilizados.

Na mesma linha de entendimento, brilhante é a observação de Lucrécia Teixeira Pinheiro (2018, p. 181):

\begin{abstract}
A informação constante do PPP no sentido de que o EPI é eficaz não pode elidir o direito à aposentadoria especial. Ora, como um empregador afirmará que o equipamento de proteção individual é ineficaz? Se não for eficaz, do ponto de vista abstrato ele poderá ser responsabilizado civilmente por eventual dano causado ao trabalhador. Outra situação é afirmar que o EPI jamais inibe que o trabalhador desenvolva algum problema de saúde em razão do fato de trabalhar em ambiente nocivo, podendo o indivíduo ter uma suscetibilidade maior, o equipamento não ser utilizado durante toda a jornada ou mesmo tal equipamento apresentar algum defeito.
\end{abstract}

Por fim, também ensinam Arthur Bragança de Vasconcelos Weintraub e Fábio Lopes Vilela Berbel (2005, p. 172) que "[...] a simples menção da utilização de EPI, na forma da Lei nº.9.732/98, também, não tem o poder de desnaturar a atividade nociva à saúde humana”.

Diante disso, denota-se, em consonância com a doutrina, que, como nenhum órgão competente comprovou a inexistência do risco à saúde do segurado pelo simples uso de EPIs, a contagem do tempo especial para fins de aposentadoria não poderia, de modo algum, ser negligenciada. 
De todo modo, ainda assim entendeu o Tribunal, mesmo tomando o devido conhecimento científico e doutrinário acerca da impossibilidade técnica de comprovação da real eficácia dos aparelhos de proteção individual. Ora, se constatado que o EPI não é capaz de conter a agressividade do ruído, como entender que o será nos demais casos? Com que fundamento, se nenhuma pesquisa técnica foi feita quanto à eficácia dos EPIs perante os demais agentes nocivos previstos no rol da NR-15 do Ministério do Trabalho? Certamente, se tal pesquisa houvesse sido feita, a incapacidade de contenção da insalubridade pelo simples uso do EPI teria sido observada. Como, então, declarar em sede de repercussão geral o contrário sem nenhuma prova?

Essas e outras questões relativas à decisão em análise deixa no ar, desconsiderando por completo a individualidade do segurado nesse contexto, que, não raramente, após tantos anos em serviço insalubre, já se encontra demasiado cansado e sobrecarregado quando da realização de seu requerimento, por vezes, com a saúde a fio.

Isso tudo sem levar em consideração os elevados índices de Perfis Profissiográficos Previdenciários que são viciados e entregues todos os dias.

Sabido que aquelas empresas que entregam aparelhos de proteção declarados "eficazes" à contenção do agente nocivo possuem isenção da metade do valor da contribuição junto ao SAT, não se pode subestimar o caráter egoístico e avarento do capital. Com efeito, após a concessão da isenção, inúmeras empresas vêm assumindo proceder corrupto por meio da adulteração de PPPs com laudos de condições ambientais de trabalho comprados e/ou, até mesmo, mediante a redação de informações falsas no tocante à entrega e eficácia de EPIs, tudo para receber o aludido incentivo e potencializar seus lucros ao máximo.

Já havia bem observado Zavascki, em suas ponderações, que os pareceres do empregador no âmbito do perfil profissiográfico previdenciário se referem a uma relação estritamente tributária, o que jamais se pode confundir com a relação previdenciária entre o segurado e o Estado.

Ademais, conforme lembra o Ministro Fux no decorrer de seu voto, se anteriormente, quando o reconhecimento da aposentadoria especial não importava em qualquer impacto patrimonial para a empresa, esta já preenchia os formulários de seus empregados com declarações completamente discrepantes para renovar com frequência sua mão de obra, que dirá agora com a renda do empreendimento em jogo?

Mais uma vez, encontra-se, também aí uma contradição que a referida decisão deixou de resolver, optando, às cegas, por favorecer a empresa em detrimento do trabalhador, com a presunção de veracidade do PPP por ela emitido. A consequência disso não poderia ser pior, inúmeros trabalhadores, efetivamente expostos a agentes nocivos e com a saúde já substancialmente degradada, deixam de fazer jus à aposentadoria especial, seja pelo fato de não conseguirem se desincumbir do ônus de provar que as declarações do PPP não condizem com a realidade, seja pelo fato de não conhecerem seus direitos, ou por terem acabado desistindo de se aposentar sob o ângulo da proteção especial, conformando-se com a injustiça.

Para além, deve-se frisar que a decisão sob julgamento não corroborou com a melhor interpretação constitucional, visto que a redação do artigo $201, \S 1^{\circ}$. da $\mathrm{CF} / 88$ vigente à época do julgado, dispunha ser vedada a adoção de requisitos e critérios diferenciados para a concessão de aposentadoria aos segurados do regime geral de previdência, com exceção 
daqueles casos de atividades exercidas sob condições especiais que prejudicassem a saúde. Ora, em momento algum o aludido dispositivo mencionava ser necessário o contato direto do trabalhador com o agente nocivo, deixando claro, em sua simples leitura, que a mera presença de condições especiais prejudiciais à saúde no ambiente de trabalho, por si só, mostrava-se suficiente para que o obreiro fizesse jus ao benefício.

Consideramos a antiga redação do dispositivo supracitado para fins de análise neste trabalho, uma vez que era a determinação legal vigente à época em que foi proferida a decisão objeto de análise. Porém, apesar da nova redação advinda com a Reforma da Previdência, ainda assim entendemos que a exigência constitucional de efetiva exposição ao agente nocivo prevista no novo artigo 201, § $1^{\circ}$., II da Constituição Federal, não pode ser interpretada no sentido de que a mera entrega de EPIs declarados pelo empregador em sede de PPP enquanto eficazes na contenção do risco seja suficiente para afastar o direito à aposentadoria especial. Antes, a hermenêutica constitucional deve se pautar na orientação que melhor favoreça a saúde e, por conseguinte, a dignidade do hipossuficiente, ou seja, caminhar no sentido de que a exigência de efetiva exposição signifique a comprovação da existência de agentes nocivos acima dos limites de tolerância no ambiente de trabalho. Até mesmo porque, conforme demonstrado, a despeito do uso de EPIs o segurado fica, ainda assim, sujeito a um risco potencial durante toda a jornada de trabalho, seja porque é impossível saber se o equipamento está sendo realmente eficaz, seja porque pode comportar algum defeito, seja porque não está sendo usado corretamente ou porque o trabalhador possui condições imunológicas mais frágeis, estando mais propenso a danos que outrem, razão pela qual não se pode, de modo algum, partir de uma análise ou experiência individual para afirmar o geral.

Por fim, mas não menos importante, tem-se aquela crítica muito bem comentada pelo Ministro Marco Aurélio a respeito do deslocamento das ações dos Juizados Especiais Federais para a primeira instância da Justiça Federal, posto que àqueles não possuem maiores espaços para discussões probatórias. É certo que o deslocamento em comento reflete, inegavelmente, na maior morosidade das ações, em verdadeiro contrassenso ao princípio da celeridade processual, quanto mais por se tratar o objeto da demanda de verba alimentar imprescindível à sobrevivência do segurado e de sua família.

Convém ressaltar que a negativa irresponsável desse benefício é passível de consequências catastróficas, entre elas, não somente a perda da saúde, como também da própria vida do trabalhador se não resguardado a tempo.

O segurado precisa ser contemplado em sua totalidade, em suas potencialidades, dignidade e bem-estar, ter o direito a uma existência saudável em todas as suas nuanças e a uma vida longínqua e feliz. Qualquer ato atentatório à saúde física e psicológica do obreiro importaria, por conseguinte, em uma grave violação à sua própria dignidade enquanto pessoa humana, posto que a saúde é um dos elementos indispensáveis à sua realização.

Lamentavelmente, o ARE 664.335 restou por desconsiderar esse preceito fundamental, supervalorizando as contas públicas em detrimento das pessoas, de modo a rebaixar o indivíduo à mera condição de coisa, instrumentalizando-o a servir aos interesses do capital e do Estado quando, na verdade, deveria ser a fonte primordial de todos os valores e proteção.

Apesar de o artigo $1^{\circ}$., III da Constituição Federal, estabelecer como fundamento do Estado Democrático de Direito a dignidade da pessoa humana, observa-se que esse precei- 
to fundamental tem sido substancialmente ignorado na prática das decisões judiciais, o que evidencia verdadeiro retrocesso social e jurídico.

Com efeito, em vez de contribuir para a paz, para o afastamento dos conflitos de interesse, proclama-se a guerra contra os menos favorecidos, povo honrado e trabalhador, que têm de lutar, até o último suspiro, para sobreviver.

É preciso que o Poder Judiciário se despoje cada vez mais de seu caráter meramente fundado em limitados elementos de obiter dictum ${ }^{2}$ e assuma, finalmente, a qualidade de ratio decidendi, ${ }^{3}$ levando-se em consideração o verdadeiro contexto social do país e não aquela romântica visão de nação justa, isonômica e solidária que eles gostam de proclamar. Somente assim estaremos efetivamente direcionados à justiça social, pela qual vale a pena lutar!

\section{CONSIDERAÇões FINAIS}

O direito à aposentadoria especial foi consagrado no intuito de resguardar ao máximo a saúde do trabalhador que labora em condições de trabalho degradantes, afastando-o, o quanto antes, daqueles agentes nocivos para the preservar a longevidade da vida com dignidade.

Porém, a despeito de anos de desenvolvimento e afirmação legal, recentemente, a aposentadoria especial tem sido alvo de significativo retrocesso social, o que vem desde a publicação do ARE 664.335 em sede de repercussão geral, até a Reforma da Previdência.

A saúde e a dignidade do trabalhador que costumavam ser objeto de amparo e proteção do Estado mediante a concessão da aposentadoria especial enquanto escape à monetização de riscos foram postas em xeque, valendo-se, antes de tudo, da supremacia das contas públicas.

O ARE 664.335 restou por consignar que a aquisição do direito à aposentadoria em discussão pressupõe uma efetiva exposição do segurado a agente nocivo à sua saúde, de modo que, se o Equipamento de Proteção Individual (EPI) for realmente capaz de neutralizar a nocividade, não haverá que se falar em aposentadoria especial, com exceção aos casos de ruído, em que restou por entender-se que é impossível a neutralização.

Tal decisão, todavia, é passível de inúmeras críticas, seja por transferir o ônus da prova ao trabalhador quando sua realização é de extrema dificuldade e de eficácia duvidosa, especialmente em um cenário onde perfis profissiográficos previdenciários vêm sendo amplamente maculados pelo capital, seja pelos deslocamentos das ações dos Juizados Especiais Federais em evidente prejuízo ao princípio da celeridade, ou ainda, em virtude do posicionamento majoritário da doutrina no sentido de se negar a completa eficácia de todos e quaisquer equipamentos de proteção individual na contenção dos agentes insalubres.

A aposentadoria especial é um benefício de extrema relevância e por essa razão precisa ser analisada com cautela, pois a sua negativa irresponsável e sem precedentes pode

2 Aquilo que está dito, mas não se relaciona exatamente ao objeto de discussão, fundamentos aleatórios, sem nenhuma justificativa palpável ou empírica que realmente corresponda à questão sob julgamento. São elementos circunstanciais que não podem ser considerados como motivo de decidir, mas como meros elementos de apoio baseados em uma opinião pessoal.

3 Fundamentos propriamente ditos, dotados de justificação lógico-racional, que consideram os sujeitos, o contexto social e a perspectiva institucional. São a verdadeira razão de decidir. 
gerar consequências catastróficas, entre elas, não somente a perda da saúde, como também da própria vida do trabalhador.

O segurado precisa ser contemplado em sua totalidade e potencialidades, ter o direito a uma existência saudável e a uma vida longínqua, sob pena de se desconsiderar sua própria dignidade enquanto pessoa humana.

Fundado em meros preceitos de obiter dictum, o STF acabou por desconsiderar tal princípio, que deveria ser, na verdade, fonte suprema e direcionadora de todo e qualquer pronunciamento judicial.

Uma decisão efetivamente calcada nos valores da justiça deveria ter considerado como fator de presunção, ainda que relativa, a ineficácia dos aparelhos de proteção na contenção dos agentes nocivos, distribuindo o ônus da prova ao INSS, de modo que somente a demonstração de que o aparelho fora, de fato, plenamente suficiente a conter o risco autorizaria a negativa do benefício, e não o contrário.

Ademais, nenhum órgão competente conseguiu comprovar a inexistência do risco à saúde do segurado pelo simples uso de EPIs, razão pela qual a contagem do tempo especial para os trabalhadores que utilizam esse tipo de equipamento em condições insalubres não poderia, de modo algum, ter sido negligenciada.

Nunca foi tão necessário que os magistrados se revestissem da ratio decidendi como agora, a fim de considerar o verdadeiro contexto histórico-social da nação para posteriormente julgar. A verdade é que, juristas ou pessoas comuns, precisamos todos buscar o progresso, jamais a regressão.

\section{REFERÊNCIAS}

AMADO, Frederico. Direito Previdenciário, 8. ed. Salvador: Juspodivm, 2017.

BRASIL. Decreto-Lei no ${ }^{\circ}$ 5.452, de $1^{\circ}$. de maio de 1943. Aprova a Consolidação das Leis do Trabalho. Diário Oficial da União, Brasília, 9 ago. 1943. Disponível em: < http://www. planalto.gov.br/ccivil_03/Decreto-Lei/Del5452.htm>. Acesso em: 6 mar. 2020.

BRASIL. Lei no. 8.212 de 24 de julho de 1991. Dispõe sobre a organização da Seguridade Social, institui Plano de Custeio, e dá outras providências. Diário Oficial da União, Brasília, 25 jul. 1991. Disponível em: http://www.planalto.gov.br/ccivil_03/LEIS/L8212cons. htm. Acesso em: 6 mar. 2020.

BRASIL. Lei nº 8.213 de 24 de julho de 1991. Dispõe sobre os Planos de Benefícios da Previdência Social e dá outras providências. Diário Oficial da União, Brasília, 25 jul. 1991. Disponível em: http://www.planalto.gov.br/ccivil_03/LEIS/L8213cons.htm. Acesso em: 6 mar. 2020.

BRASIL. Decreto nº 3.048, de 6 de maio de 1999. Aprova o Regulamento da Previdência Social, e dá outras providências. Diário Oficial da União, Brasília, 7 de maio de 1999. Disponível em: http://www.planalto.gov.br/ccivil_03/decreto/D3048.htm. Acesso em: 6 mar. 2020. 
BRASIL. Conselho de Recursos do Seguro Social. Enunciado no. 21. O simples fornecimento de equipamento de proteção individual de trabalho pelo empregador não exclui a hipótese de exposição do trabalhador aos agentes nocivos à saúde, devendo ser considerado todo o ambiente de trabalho. Diário Oficial da União, Brasília, 18 nov. 1999.

BRASIL. Lei $n^{\circ}$. 10.666, de 8 de maio de 2003. Dispõe sobre a concessão da aposentadoria especial ao cooperado de cooperativa de trabalho ou de produção e dá outras providências. Diário Oficial da União, Brasília, 9 de maio de 2003. Disponível em: < http:/www.planalto.gov.br/ccivil_03/leis/2003/L10.666.htm>. Acesso em: 6 mar. 2020.

BRASIL. Turma Nacional de Uniformização dos Juizados Especiais Federais. Súmula nº 09. O uso de Equipamento de Proteção Individual (EPI), ainda que elimine a insalubridade, no caso de exposição a ruído, não descaracteriza o tempo de serviço especial prestado. Diário Oficial da União, Brasília, 17 out. 2003.

BRASIL. Constituição da República Federativa do Brasil. In: VADE Mecum Compacto de Direito, 11. ed. São Paulo: Rideel, 2016.

BRASIL. Supremo Tribunal Federal. Agravo em Recurso Extraordinário 664335. Relator: Ministro Luiz Fux. Diário de Justiça Eletrônico, 12 fev. 2015. Disponível em: http://portal. stf.jus.br/processos/downloadPeca.asp?id=299157262\&ext=.pdf . Acesso em: 6 mar. 2020.

BRASIL. Emenda Constitucional nº. 103, de 12 de novembro de 2019. Altera o sistema de previdência social e estabelece regras de transição e disposições transitórias. Diário Oficial da União, Brasília, 13 nov. 2019. Disponível em: < http://www.planalto.gov.br/ccivil_03/ constituicao/Emendas/Emc/emc103.htm\#art1>. Acesso em: 13 mar. 2020.

CASSAR, Vólia Bomfim. Direito do Trabalho, 14. ed. Rio de Janeiro: Forense, 2017.

DELGADO, Maurício Godinho. Curso de Direito do Trabalho, 15. ed. São Paulo: LTr, 2016.

GOMES, Dinaura Godinho Pimentel. O princípio constitucional da dignidade da pessoa humana e a flexibilização da legislação trabalhista. Revista de Direito Constitucional e Internacional, São Paulo, v. 11, n. 44, jul./set. 2003.

GONÇALVES, Antônio Fabrício de Matos. Flexibilização Trabalhista, 2. ed. Belo Horizonte: Mandamentos, 2007.

IBRAHIM, Fábio Zambitte. Curso de Direito Previdenciário, 20. ed. Rio de Janeiro: Impetus, 2015.

KANT, Immanuel. Textos selecionados: fundamentação da metafísica dos costumes. Sel. Marilena Chaú. Trad. Maria Bernkopf, Paulo Quintela e Rubens Rodrigues Torres Filho. São Paulo: Abril Cultural, 1980. 
KWITKO, Airton. EPIs Auditivos: a irrealidade DOP NRR E NRR-SF, escolha individual, tempo de vida útil, EPIs para motoristas e outros tópicos sobre audiologia ocupacional. São Paulo: LTr, 2006.

LUCA, Tânia Regina de. Direitos sociais no Brasil. In: PINSKY, Jaime; PINSKY, Carla Bassanezi (orgs.). História da cidadania, 6. ed. São Paulo: Contexto, 2013.

MARTINEZ, Wladimir Novaes. Questões atuais envolvendo a aposentadoria especial. Revista de Previdência Social, Brasília, n. 217, dez. 1998.

NASCIMENTO, Lauriene do; VIEGAS Cláudia Mara de Almeida. Flexibilização das normas trabalhistas como ônus da crise econômica: o trabalhador pagará a conta? Revista de Direito do Trabalho. São Paulo, v. 42, n. 170, jul./ago. 2016.

PINHEIRO, Lucrécia Teixeira. Aposentadoria Especial do Eletricista. In: SANTOS, Roberto de Carvalho (org.). Direito Previdenciário: primeira coletânea de artigos do curso de especialização em Direito Previdenciário. Belo Horizonte: IEPREV, 2018. Disponível em: $<$ https://www.ieprev.com.br/assets/docs/120618-EBOOK.pdf>. Acesso em: 13 mar. 2020.

RIBEIRO, Maria Helena Carreira Alvim. Aposentadoria Especial: regime geral da previdência social, 2. ed. Curitiba: Juruá, 2007.

RUDIGER, Susanne Dorothee. Teoria da flexibilização do Direito do Trabalho: uma tentativa de contextualização histórica. Prima@ Facie: Revista da Pós-Graduação em Ciências Jurídicas, João Pessoa, v. 3, n. 4, jan./jun. 2004. Disponível em: < http://periodicos.ufpb.br/ ojs/index.php/primafacie/article/view/4455>. Acesso em: 6 mar. 2020.

TEIXEIRA, Carolina de Souza Novaes Gomes; ALACOQUE, Lucas Scarpelli de Carvalho. Adicionais legais e seus aspectos polêmicos. Revista Paradigma. Ribeirão Preto, v. XVIII, n. 22, jan./dez. 2013.

WEINTRAUB, Arthur Bragança de Vasconcelos; BERBEL, Fábio Lopes Vilela.

Manual de Aposentadoria Especial. São Paulo: Quartier Latin, 2005.

\section{DÉbora de JeSus REZENDE BARCELOS}

Mestranda no Programa de Pós-graduação em Direito da Pontifícia Universidade Católica de Minas Gerais com bolsa de pesquisa do CNPq. Especialista em Direito do Trabalho e Previdenciário pela mesma instituição. Bacharel em Direito pela Faculdade Mineira de Direito da Pontifícia Universidade Católica de Minas Gerais (PUC Minas). E-mail: deboradejesus.barcelos@gmail.com.

Submetido em:26-6-2020

Aceito em: 30-8-3030 